Kodifikasia : Jurnal Penelitian Islam, Vol 15, No. 02 (2021), 209-227

DOI : 10.21154/kodifikasia.v15i2.3197

ISSN : 1907-6371 (Cetak)

ISSN : 2527-9254 (Online)

\title{
THE RELATIONS OF SOCIAL ACTION AND RELIGIOUS DISCOURSES IN THE PHENOMENON OF TOLAK BALA “DISASTER PREVENTION” OF COVID-19 IN TINGGIRAN VILLAGE, BATOLA
}

\author{
Riza Saputra*, Maghfirah**
}

\begin{abstract}
Abstrak:
Artikel ini membahas fenomena kegiatan pencegahan bencana atau "tolak bala" Covid-19 yang dilakukan oleh masyarakat Desa Tinggiran Baru, Barito Kuala. Kegiatan ini diasumsikan oleh masyarakat sekitar dapat menghentikan dan menangkal virus Corona. Namun, hasil sebenarnya yang diperoleh dari kegiatan ini masih belum pasti. Oleh karena itu, menarik untuk mengetahui mengapa masyarakat di Desa Tinggiran melakukan ritual tolak bala untuk mencegah bencana covid-19. Untuk menjawab pertanyaan ini, kami menggunakan teori tindakan sosial yang disandingkan dengan wacana keagamaan dalam pandangan Max Weber dan mengumpulkan data dengan observasi, wawancara, dan dokumentasi. Dengan menggunakan metode kualitatif dan pendekatan fenomenologi, hasil penelitian ini mengarah pada beberapa poin: Pertama, peran narasi sejarah-tradisional, pandangan masyarakat desa terhadap kegiatan tolak bala terbentuk dari peristiwa sejarah yang berurutan bahwa tolak bala adalah hal yang biasa. aktivitas dan selalu menjadi alternatif untuk menghadapi situasi tersebut. Kedua, peran emosional-afeksi, dalam kegiatan tolak bala emosi merupakan salah satu faktor penentu yang mendukung keinginan masyarakat untuk melakukan kegiatan ini, Ketiga, peran tokoh agama dan kharismanya dalam struktur sosial desa Tinggiran Baru telah memperkuat narasi keagamaan dan mendorong masyarakat untuk mematuhi seruan kegiatan tolak bala.
\end{abstract}

Kata kunci: Tolak Bala; Covid-19; Diskursus Agama; Aksi Sosial. ac.id

* Universitas Islam Negeri Antasari Banjarmasin, email: Rizasaputra@uin-antasari.

** Universitas Islam Negeri Antasari Banjarmasin, email: magfirahclawy@gmail.com 


\begin{abstract}
:
This study discusses the phenomenon of disaster prevention activity or "tolak bala" of Covid-19 practiced by the villagers of Tinggiran Baru, Barito Kuala. The local people assume this activity can stop and ward off Coronavirus. However, the actual result obtained from this activity is still uncertain. Thus, it is exciting to know why people in Tinggiran village practice a tolak bala to prevent the covid-19 disaster. We use social action theory juxtaposed with religious discourse in Max Weber's view and collect the data with observation, interview, and documentation to answer this question. The results of this study lead to several points: First, the role of traditional-historical narrative, the view of villagers on tolak bala activity formed by the successive historical events that tolak bala is a common activity always becomes an alternative to deal with such situation. Second, the role of emotional-affectional in tolak bala activity is one of the determining factors that support the community's desire to do this activity. Third, the role of religious leaders and their charisma in the social structure of the village Tinggiran Baru has strengthened the sacred narrative and encouraged people to obey the call of tolak bala activity.
\end{abstract}

Keywords: Tolak bala; Covid-19; Religious discourses; Social action.

\title{
INTRODUCTION
}

The Covid-19 that broke out in early 2020 has changed various lifelines and threatens to paralyze the economy in every country. The existence of the virus has led to different reactions from the public, ranging from panic leading to hoarding of food ingredients to a dismissive attitude that causes the spread of the virus to accelerate. These social phenomena are a reality of the society's life that show diverse characteristics of action; even in society itself, motives for action between individuals will are not uniform and have a different meaning. ${ }^{1}$ The Covid-19 pandemic situation in Indonesia is incidentally rich in culture and tradition.

Several scholars who studied the Pandemic of Covid-19 have emphasized that the issue of the Covid-19 Pandemic focuses on health

${ }^{1}$ Sindung Haryanto, Spektrum Teori Sosial : Dari Klasik Hingga Kontemporer. Yogyakarta: Ar-Ruzz Media, 2012, 137.

Kodifikasia: Jurnal Penelitian Islam, Volume, 15 No. 2 Tahun 2021 
problems involving the social dimension, ${ }^{2}$ psychological, ${ }^{3}$ politics,${ }^{4}$ culture,${ }^{5}$ education, ${ }^{6}$ and even religion ${ }^{7}$ the belief of the people themselves. In faith, the Pandemic is one of the problems scholars have received much attention. ${ }^{8}$

In the context of the response of the religious groups, Arrobi and Nadzifah explained that religion does have a significant role as a power

${ }^{2}$ Yusuf Setyadi, "Social And Security Impact Of Covid-19 Outbreak In West Kalimantan Based On The Police Law Perspective," Syariah: Jurnal Hukum Dan Pemikiran 20, no. 1 (July 2, 2020): 13-26, https://doi.org/10.18592/sjhp.v20i1.3771; Muchammad Bayu Tejo Sampurno, Tri Cahyo Kusumandyoko, and Muh Ariffudin Islam, "Budaya Media Sosial, Edukasi Masyarakat, dan Pandemi COVID-19," SALAM: Jurnal Sosial dan Budaya Syar-i 7, no. 6 (April 14, 2020): 529-42, https://doi.org/10.15408/sjsbs.v7i5.15210; Budi Yanti et al., "Community Knowledge, Attitudes, And Behavior Towards Social Distancing Policy As Prevention Transmission of Covid-19 In Indonesia," Jurnal Administrasi Kesehatan Indonesia 8, no. 0 (June 17, 2020): 4-14, https://doi.org/10.20473/jaki.v8i0.2020.4-14.

3 Wenjun Cao et al., "The Psychological Impact of the COVID-19 Epidemic on College Students in China," Psychiatry Research 287 (May 2020): 112934, https://doi. org/10.1016/j.psychres.2020.112934; Hazhar Talaat Abubaer Blbas et al., "Phenomenon of Depression and Anxiety Related to Precautions for Prevention among Population during the Outbreak of COVID-19 in Kurdistan Region of Iraq: Based on Questionnaire Survey," Zeitschrift Fur Gesundheitswissenschaften = Journal of Public Health, June 10, 2020, 1-5, https://doi.org/10.1007/s10389-020-01325-9.

${ }^{4}$ Aquarini Aquarini, "Pengaruh Kebijakan Politik Terhadap Kepatuhan Physical Distancing Mencegah Penyebaran Covid-19," Anterior Jurnal 19, no. 2 (June 30, 2020): 66-73, https://doi.org/10.33084/anterior.v19i2.1498.

${ }^{5}$ Dadang Kahmad et al., "Ritual Azan Pitu sebagai upaya mencegah penyebaran wabah Covid-19 di Cirebon," Monograph, Karya Tulis Ilmiah Dosen UIN Sunan Gunung Djati Bandung (UIN Sunan Gunung Djati Bandung: Fakultas Ushuluddin, May 2, 2020), http://digilib.uinsgd.ac.id/30628/.

${ }^{6}$ Cao et al., "The Psychological Impact of the COVID-19 Epidemic on College Students in China"; Azmil Abidah et al., "The Impact of Covid-19 to Indonesian Education and Its Relation to the Philosophy of 'Merdeka Belajar," Studies in Philosophy of Science and Education 1, no. 1 (April 1, 2020): 38-49, https://doi.org/10.46627/sipose.v1i1.9.

7 Stephen M. Modell and Sharon L. R. Kardia, "Religion as a Health Promoter During the 2019/2020 COVID Outbreak: View from Detroit," Journal of Religion and Health 59, no. 5 (October 1, 2020): 2243-55, https://doi.org/10.1007/s10943-020-01052-1; Curtis W. Hart and Harold G. Koenig, "Religion and Health During the COVID-19 Pandemic," Journal of Religion and Health 59, no. 3 (June 2020): 1141-43, https://doi.org/10.1007/ s10943-020-01042-3; Siti Khodijah Nurul Aula, "Peran Tokoh Agama Dalam Memutus Rantai Pandemi Covid-19 Di Media Online Indonesia," Living Islam: Journal of Islamic Discourses 3, no. 1 (June 28, 2020): 125-48, https://doi.org/10.14421/lijid.v3i1.2224; M. Alkaf, "Agama, Sains, Dan Covid-19: Perspektif Sosial-Agama," MAARIF 15, no. 1 (June 30, 2020): 93-108, https://doi.org/10.47651/mrf.v15i1.79.

${ }^{8}$ Nur Hidayah, "Dari Jabariyah, Ke Qadariyah, Hingga Islam Progresif: Respons Muslim Atas Wabah Corona Di Indonesia," SALAM: Jurnal Sosial Dan Budaya Syar-i 7, no. 5 (April 17, 2020): 423-38, https://doi.org/10.15408/sjsbs.v7i6.15365; Dadang Kuswana, Bambang Qomaruzzaman, and Masmuni Mahatma, "Agama Dan Wabah: Tanggapan Ulama Jawa Barat Atas Covid-19 Tahun 2020," UIN Sunan Gunung Djati Bandung, 2020, http://digilib.uinsgd.ac.id/30780/; Alkaf, "Agama, Sains, Dan Covid-19"; Mohammad Zaki Arrobi and Amsa Nadzifah, "Otoritas Agama di Era Korona: Dari Fragmentasi Ke Konvergensi?," MAARIF 15, no. 1 (June 30, 2020): 197-215, https://doi.org/10.47651/ mrf.v15i1.85. 


\section{2 | Riza Saputra, Maghfirah}

that encourages its adherents to participate in mitigating the epidemic. However, religion can also be a power that prevents its followers from mitigating the epidemic. Religion as an authoritative power in its form as religious organizations, religious institutions, and religious leaders play a role in preventing, ranging from socialization, education, and protection of the epidemics spread among religious people. As for religion as a destructive force that causes the spread of this epidemic through ceremonial activities involving large crowds. ${ }^{9}$

One of the interesting phenomena in the Covid-19 pandemic situation in the village of Tinggiran Baru, Mekarsari District, Barito Kuala Regency, South Kalimantan, was the activity of Tolak Bala "disaster prevention or ward off misfortune" of the Covid-19 carried out by the local community. In response to the Pandemic, the community carried out tolak bala activity by boiling free-range chicken eggs and reading a congratulatory prayer. The villagers hope that eating these boiled eggs could avoid the Coronavirus infection (Covid-19).

Although the source of information, tolak bala activity, is still unclear and confusing, it does not make people hesitant to implement it. Even they consider that tolak bala is sacred because it contains Islamic religious elements. Departing from this phenomenon, the author intends to know why the people of Tinggiran Baru village want to recommend local religious figures in practicing tolak bala. However, this research is not studying religion in a normative sense (true-false) but instead trying to objectively see the relationship between social actions of the community concerning the influence of religion. Therefore, Max Weber's theory of social action dissected the phenomenon of tolak bala activity of the Covid-19 in the Tinggiran Baru village.

Max Weber's theory of action tries to understand the structure of society from the uniqueness of individual social activities so that Weber's theory of social action cannot claim generalization. Weber's theory of action only tries to identify why and how social action is built-in society. ${ }^{10}$ To emphasize the main issues under study, the author focuses on studying the motives for social activity of the people of Tinggiran Baru Village in carrying out the rejection of the Covid-19 reinforcements and their relationship with religious narratives.

${ }^{9}$ Mohammad Zaki Arrobi and Amsa Nadzifah, "Otoritas Agama di Era Korona: Dari Fragmentasi Ke Konvergensi?," MAARIF 15, no. 1 (June 30, 2020): 197-215, https://doi. org/10.47651/mrf.v15i1.85.

${ }^{10}$ Pip Jones, Liz Bradbury, dan Shaun Le Boutillier, Pengantar Teori-teori Sosial, translated by. Achmad fedyani. Jakarta: Yayasan Pustaka Obor, 2016, 120-121.

Kodifikasia: Jurnal Penelitian Islam, Volume, 15 No. 2 Tahun 2021 
This research is a type of field research with a micro research scope (Single social situation). The location is Tinggiran Baru village in Mekarsari District, Barito Kuala Regency, South Kalimantan. The research object is the Covid-19 tolak bala activity concerning the motives of the community's social actions. Thus the Tinggiaran Baru village community who carries out this tolak bala activity will automatically become the subject of research; the time of the study takes place from April to May 2020.

According to Auerbach and Silverstein, the method used in this study is a qualitative method, as quoted by Sugiyono in their book, Methods of Qualitative Research, which states that this method aims to find and understand the meaning of a phenomenon through analysis and interpretation of texts and interview results. ${ }^{11}$ Based on this statement, we considered an appropriate method for studying the phenomenon of Covid-19 tolak bala activity in the Tinggiran Baru village to be a phenomenological approach.

In addition, the qualitative method uses the principles of post positivistic philosophy, namely research on an object that makes the researcher the main instrument and data collection techniques using triangulation (a combination of observation, interviews, and documentation). The data obtained from the three methods will divide into primary and secondary data. Preliminary data in this study include natural phenomena related to the research object. At the same time, secondary data is additional data that has relevance and relevance to the thing of research or the scalpel used, in this case, the theory of social action from Max Weber's perspective.

This study used purposive sampling and snowball sampling in determining key informants. Purposive sampling is the technique of taking a particular data source-based criteria, while informants selected in this study were; (1) People who can provide information about the repulsion of covid-19 or tolak bala activity in Tinggiran Baru Village. (2) People who directly participate in the tolak bala activity. The snowball sampling is a technique in which the selection of informants will stop when the data found are saturated, in the sense that adding more informants will not produce additional data.

Based on these criteria, the informants in this study amounted to 7 people consisting of ordinary people and religious leaders; as quoted in the Qualitative Research Method by Sugiyono, the search for research data will stop when the data obtained are saturated. ${ }^{12}$ Various data received will be analyzed throughout the research. The technique used is a descriptive technique with data classification steps to present systematic description

\footnotetext{
${ }^{11}$ Sugiyono, Metode Penelitian Kualitatif. Bandung: Alvabeta, 2018, 3.

${ }^{12}$ Sugiyono, Metode Penelitian Kualitatif, 97.
} 


\section{4 | Riza Saputra, Maghfirah}

data. The data is then tested for validity by cross-checking triangulation data.

\section{DISCUSSIONS}

\section{The Covid-19 Pandemic and the Social Dynamics of Indonesian}

Society, The world community, was shocked by information from the world health (World Health Organization) on December 31, 2019, regarding the emergence of a new disease outbreak whose etiology was unclear in Wuhan, China. On January 30, 2020, WHO declared this outbreak a public health emergency troubling the world. Until February 12, 2020, the virus that caused the pneumonia was officially named Coronavirus Disease (Covid 19). ${ }^{13}$

This virus outbreak is highly contagious; the transmission can occur through aerosol droplets from infected people. Through direct contact, the virus can also survive for a relatively long time in the air and on the surface of objects so that this virus can spread quickly. ${ }^{14}$ Reporting from tirto.id from December 31, 2019, to May 15, 2020, positive cases of Covid-19 in the world have reached 4,454. One hundred sixty-seven people with a total death of 303,849 people and 1,715,862 people were declared cured, while 2,525,456 patients were still being treated. This epidemic is reported to have infected 213 countries, including Indonesia. As of May 15, 2020, there were 16,496 positive cases in Indonesia, with 3,803 people declared cured and 1,076 dying. ${ }^{15}$

This new virus has caused global panic, so that various countries, including Indonesia, are trying different ways to suppress its spread. The Indonesian government has declared a disaster emergency status since February 29, 2020. One of the efforts chosen is to socialize the movement's social distancing; as a consequence of this policy, schools are closed and replaced by learning through online platforms and some work that is possible to do from home. ${ }^{16}$

${ }^{13}$ Fathiyah Isbaniah et.al, Pedoman Kesiapsiagaan Menghadapi Coronavirus Disease (Covid-19). Jakarta: Kementerian Kesehatan RI Direktorat Jenderal Pencegahan dan Pengendalian Penyakit (P2P), 2020, 4.

${ }^{14}$ Safrizal ZA et.al, Pedoman Umum Menghadapi Pandemi Covid-19. Jakarta: Tim Kerja Kementerian dalam Negeri untuk Dukungan Gugus Tugas Covid-19, 2020, 5.

${ }^{15}$ M. Idhom Adidi, "Update Corona 15 Mei 2020 di Indonesia dan Dunia: Data kasus Terkini" in https://amp.tirto.id/update-corona-15-Mei-2020-di-indonesia-dunia-datakasus-terkini-fumo. accessed on 15 May 2020.

${ }^{16}$ Dana Riksa Buana, "Analisis Perilaku Masyarakat Indonesia dalam Menghadapi Pandemi Virtus Corona (Covid-19) dan Kiat Menjaga Kesehatan Jiwa" Laporan Penelitian. Jakarta: Fakultas Psikologi Nasional ResearchTomsk State, 2020, 2.

Kodifikasia: Jurnal Penelitian Islam, Volume, 15 No. 2 Tahun 2021 
The hashtag \#dirumahaja aims to break the chain of the spread of covid-19, although some jobs still require people to be active outside the home. This Pandemic creates a dilemma between humanity and the weakening of the country's economy. As the Minister of Finance of the Republic of Indonesia stated, Sri Mulyani said that the crisis was more complex than in 1997-1998 and 2008-2009 of trade activity. ${ }^{17}$

Various new policies initiate because of the Pandemic. Health manuals published, the government gives miscellaneous medical test kits, emergency hospitals, social assistance, some workers laid off, and the MUI fatwa was also present. Meanwhile, the number of positive COVID-19 patients continues to grow, so the government has issued a new policy, namely the Large-Scale Social Limitation (PSBB) in Government Regulation No. 21 of $2020 .{ }^{18}$

The Indonesian Ulama Council issued a Fatwa related to the Covid-19 Pandemic, for example, the Number 14 of 2020 concerning the Implementation of Worship in Situations of the Covid-19 Outbreak. ${ }^{19}$ MUI Fatwa No. 17 of 2020 concerning Guidelines for Prayers for Health Workers Who Use Personal Protective Equipment (PPE) when Caring for and Handling Covid-19 Patients..$^{20}$ MUI Fatwa Number 18 of 2020 involving Guidelines for the Management of Muslim Bodies (Tajhiz Al-Jana'iz) infected with Covid -19. ${ }^{21}$ MUI Fatwa No. 28 of 2020 regarding Guidelines for the Kaifiat of Takbir and Eid Prayer During the Covid-19 Pandemic. ${ }^{22}$

These fatwas contain guidelines for implementing Islamic religious worship adapted to pandemic conditions and broadly in line with government appeals and health protocols, such as calls to stay away from crowds, postpone activities that involve many people, and worship at home

${ }^{17}$ Estro Dariatno Sihaloho, "Dampak Covid-19 Terhadap Perekonomian Indonesia". Bandung: Departemen Ilmu Ekonomi Universitas Padjadjaran, 2020, 4.

${ }^{18}$ Deti Mega Purtamasari, "Kebijakan Presiden Terkait Penanganan Covid-19 disebut Bisa Berubah" in https://amp.kompas.com. Accessed on 15 May 2020.

${ }^{19}$ Majelis Ulama Indonesia, "Fatwa Majelis Ulama Indoesia Nomor 14 Tahun 2020 tentang Penyelenggaraan Ibadah dalam Situasi Terjadi Wabah Covid-19”. Jakarta: Komisi Fatwa MUI, 2020, 1.

${ }^{20}$ Majelis Ulama Indonesia, "Fatwa Majelis Ulama Indoesia Nomor 17 Tahun 2020 tentang Pedoman Kaifiat Shalat Bagi Tenaga Kesehatan yang Memakai Alat Pelindungan Diri (APD) Saat Merawat dan Menangani Pasien Covid-19". Jakarta: Komisi Fatwa MUI, 2020, 1.

${ }^{21}$ Majelis Ulama Indonesia, "Fatwa Majelis Ulama Indoesia Nomor 18 Tahun 2020 tentang Pedoman Pengurusan Jenazah (Tajhiz Al-Jana’iz) Muslim yang Terenfeksi Covid-19”. Jakarta: Komisi Fatwa MUI, 2020, 1.

${ }^{22}$ Majelis Ulama Indonesia, "Fatwa Majelis Ulama Indoesia Nomor 28 Tahun 2020 tentang Panduan Kaifiat Takbir dan Shalat Idul Fitri Saat Pandemi Covid-19”. Jakarta: Komisi Fatwa MUI, 2020, 1. 
and others. ${ }^{23}$ Although it is formulated based on the rules of Ushul fiqh, there are still many people who do not take the fatwa seriously, and some consider it trivial.

According to Dana Riksa Buana from Mercu Buana University. Based on her findings, Riksa claims that the factor for the disobedience of some Indonesians to the government's appeal and the bodies that have authority in dealing with Covid-19 is cognitive bias, namely systematic errors in thinking. These errors include; unrealistic optimism about the selfconfidence that can avoid the virus without being accompanied by genuine efforts, emotional factors, and the bias of textual religious beliefs. ${ }^{24}$

\section{Tolak Bala Covid-19 in Tinggiran Baru Village}

Tolak Bala consists of two words, namely "tolak" which means rejection or an attempt to avoid, while "bala" means danger or disaster. Avoiding the disaster is an activity carried out to ward off threats that might come. In anthropology, tolak bala is a form of ritual. Rites are usually performed to obtain blessings, bring sustenance, ward off harm or treat illness. ${ }^{25}$

In traditional community groups, tolak bala becomes a rooted tradition carried out at certain times or conditions. Various rules have been mixed with religion in its development, including Islam. a practice influenced by religious teachings will usually undergo some changes and adjustments so that the method remains but does not conflict with religious beliefs. ${ }^{26}$

The activity of tolak bala contains the belief that it can prevent people or communities who carry it out from various dangers such as crop failure, natural disasters, and disease. The people of Tinggiran Baru village carried out activities to resist the Covid-19 reinforcements to prevent the spread of the virus. Thus, it can be assumed that the people of Tinggiran village only think that the Covid-19 Pandemic is a "revenge" or "doom." ${ }^{27}$ M. Quraish Shihab, in his writing Corona Trials of God, denies the assumption that Covid 19 is a reinforcement or punishment that God has sent down because of anger. The Quran has explained that if God wants to impose punishment,

\footnotetext{
${ }^{23}$ Majelis Ulama Indonesia, "Fatwa Majelis Ulama Indoesia Nomor 14 Tahun 2020 tentang Penyelenggaraan Ibadah dalam Situasi Terjadi Wabah Covid-19", 8-9.

${ }^{24}$ Dana Riksa Buana, "Analisis Perilaku Masyarakat Indonesia dalam Menghadapi Pandemi Virus Corona (Covid-19) dan Kiat Menjaga Kesehatan Jiwa," 4-6.

${ }^{25}$ Hasbullah, Toyo, and Awang Azman Awang Pawi, "Ritual Tolak Bala Pada Masyrakat Melayu (Kajian Pada Masyarakat Petalang Kecamatan Pangkalan Kuras Kabupaten Pelalawan" Jurnal Uushuluddin, Vol. 25, No. 1 January-June 2017, 90.

${ }^{26}$ Hasbullah, Toyo, and Awang Azman Awang Pawi, "Ritual Tolak Bala Pada Masyrakat Melayu (Kajian Pada Masyarakat Petalang Kecamatan Pangkalan Kuras Kabupaten Pelalawan", 84.

${ }^{27}$ Interview with Y, a villager in Tinggiran Baru village on May, 10th 2020.
}

Kodifikasia: Jurnal Penelitian Islam, Volume, 15 No. 2 Tahun 2021 
the believers will be saved first. In contrast to the spread of Covid-19, an assumption that this Pandemic is the punishment was a mistake, beyond that M. Quraish Shihab be agreed if this virus pandemic situation is considered a test from God.25 Regardless of the view that Covid-19 is a punishment or just a test. The tolak bala activity against Covid-19 is outside the recommendation of the government, health authorities, and the Indonesian Ulama Council, so it is essential to see how the people of Tinggiran Baru village assume and believe that this activity can protect them from the spread of the virus.

1. Sources of Information on the Implementation of Tolak Bala

Tolak Bala activity of the Covid-19 in the village of Tinggiran Baru started from the spread of information regarding the recommendation of tolak bala activity that can prevent the spread of the epidemic in the town. One version of the story regarding the source of information explains that the suggestion came from a religious figure in the village of Tinggiran Baru with the initials B, who dreamed. KH. M Zaini bin Abdul Ghani (Guru Sekumpul) urges the public to do a tolak bala by boiling free-range chicken eggs with a congratulatory prayer; he said that this activity protects the public from exposure to the Covid-19 outbreak. ${ }^{28}$ However, the story differed after confirmation was made to the religious figure with B's initials. B never said that the suggestion came from a dream; he confirmed the information from a man who visited his house in mid-April 2020; he said he lived in Martapura (near residence KH. M Zaini bin Abdul Ghani). One of the children of Guru Sekumpul dreamed that he would give tolak bala advice against the Covid-19.29

The truth of the information source was further blurred when B explained that he did not know the man who conveyed the information to him. The validity of the origin of information was also increasingly untraceable because $B$ did not ask the person's name..$^{30}$ In another version, one of the informants stated that the information was obtained from a broadcast message on the WhatApps application; it is different from the two versions above. In this version, the source of information is said to come from a newborn baby who can speak. ${ }^{31}$ Various confusions from the basis of the recommendation to do an activity of tolak bala Covid-19 in the village of Tinggiran Baru show many gaps in uncertainty and raise many doubts. However, the local community continues to implement it.

${ }^{28}$ M. Quraish Shihab, Corona Ujian Tuhan: Sikap Muslim Menghadapinya. Tangerang: Lentera Hati, 2000, 6-8.

${ }^{29}$ Interview with B. a religious figure in Tinggiran Baru village, on May, 2nd 2020.

${ }^{30}$ Interview with B. a religious figure in Tinggiran Baru village, on May, 2nd 2020.

${ }^{31}$ Interview with NA. a villager in Tinggiran Baru village, on May, 10th 2020. 
2. The Process of Implementation of Tolak bala

The tolak bala is carried out in each house by preparing new free-range chicken eggs (not yet incubated); the eggs are then boiled until cooked, read a congratulations prayer, and then eaten with the whole family. There is no limit to the number of boiled eggs in one family, and if it can only get one egg, then one egg can be divided among each family member. The time is not determined. ${ }^{32}$ In the version from another informant, the number of boiled eggs must match the number of people in the family; if there are five people, the number of eggs must be five eggs, not necessarily free-range chicken eggs. However, the implementation must be at midnight. ${ }^{33}$

3. Motives for Social Action and Community Compliance

The motives or reasons underlying the compliance of the community in Tinggiran Baru Village in carrying out COVID-19 repulsions are, among others, because;

a. Tolak Bala is a tradition passed down from generation to generation; it is a habit that has always been carried out from generation to generation by the people of Tinggiran Baru village. Although in various forms and situations, the concept of tolak bala itself has been deeply rooted to be accepted by the community. ${ }^{34}$

b. Tolak Bala represents social identity. As a tradition attached to life, rejecting reinforcements itself has become a characteristic or originality of the people of Tinggiran Baru village. ${ }^{35}$

c. Tolak Bala is trusted from time to time; tolak Bala is one of the main alternatives in solving problems so that local people do tolak bala as a kind of fortress of protection. ${ }^{36}$

d. The tradition is part of the form of loyalty to belief: Loyalty has been believed for a long time from generation to generation allows people to comply with this without much consideration because it relates to aspects of tradition. 35

e. Anxiety about the potential related to the Covid-19 virus: Anxiety can cause panic that encourages someone to do something spontaneously; in this case, fear is one of the motives that make the people of Tinggiran Baru village carry out Tolak Bala activity. ${ }^{37}$

\footnotetext{
${ }^{32}$ Interview with B. a religious figure in Tinggiran Baru village, on May, 2nd 2020.

${ }^{33}$ Interview with S. a villager in Tinggiran Baru village, on May, 2nd 2020.

${ }^{34}$ Interview with H. a villager in Tinggiran Baru village, on May, 10th 2020.

${ }^{35}$ Interview with NA. a villager in Tinggiran Baru village, on May, 10th 2020.

${ }^{36}$ Interview with A. a villager in Tinggiran Baru village, on May, 10th 2020.

${ }^{37}$ Interview with NA. a villager in Tinggiran Baru village, on May, 10th 2020.
} 
f. Admiration to the religious leaders, fanaticism towards charismatic religious leaders make people believe and, without doubt, follow the call to practice Tolak Bala, which source is said to come from a charismatic figure. ${ }^{38}$

g. Hope for a sense of security: The combination of belief in tradition and love for figures builds hope in the hearts of the community that the activity of tolak bala can indeed increase the dangers posed by Covid-19. ${ }^{39}$

\section{Social Action and Its Relationship with Religious Discourse}

Max Weber argued that individuals and their social actions form social reality and the structure of society. At the same time, the way of life is manifested by choices that have certain motives; thus, understanding the social reality of tolak bala of Covid-19 that is done by the Tinggiran Baru village community is necessary to know how the community makes choices in practicing it. ${ }^{40}$

In Weber's perspective, social action is defined as individual actions that can influence others and include all kinds of actions that have meaning both for the individual and for others. Social action can also be in the form of a response to the actions of others, actions that are subjective and mental and influenced by specific situations, so that in this sense, a person acts not only to do something but places himself based on the motives and goals to be achieved. ${ }^{41}$

Weber classifies social action based on the standard of the rationality of the motive for action, the rationality of the action in question is related to logical and conscious consideration, then broadly speaking; the social action is divided into rational and non-rational actions. Furthermore, a reasonable action is for instrumental rationality and value rationality, while non-rational actions include affective and traditional types of action. ${ }^{42}$ First, instrumental rationality is an action that reflects the efficiency and effectiveness of action in achieving goals; this action is created through an analytical balance. Second, the type of value rationality action is a goaloriented action related to specific values; this action combines conscious consideration and belief in a matter, such as the value of humanity. Third, affectional actions are actions dominated by emotional motives and

\footnotetext{
${ }^{38}$ Interview with Y. a villager in Tinggiran Baru village, on May, 2nd 2020.

${ }^{39}$ Interview with B. a religious figure in Tinggiran Baru village, on May, 2nd 2020.

${ }^{40}$ Pip Jones, Liz Bradbury, and Shaun Le Boutillier, Pengantar Teori-teori Sosial, 117.

${ }^{41}$ I.B Wirawan, Teori-teori Sosial dalam Tiga Paradigma. Cet IV, Jakarta: Kencana, 2015, 134.

${ }^{42}$ Pip Jones, Liz Bradbury, and Shaun Le Boutillier, Pengantar Teori-teori Sosial, 118.
} 
feelings. These actions are usually created spontaneously without conscious reflection on what is being done. Fourth, traditional actions are carried out based on habits that have been carried out from time to time so that they do not require a reflection first. ${ }^{43}$

Based on these four types of actions, it can be identified that the motives for community action in carrying out tolak bala of Covid-19 in the village of Tinggiran Baru lead to traditional types of activity and affectional efforts, as follows;

In terms of conventional actions, the people of Tinggiran Baru village view tolak bala as:

1. Sacred traditions that have been passed down from generation to generation

2. Community identity

3. Activities are believed to be from time to time as the right step in dealing with the threat of distress

4. Traditions that are part of the existing loyalty to belief Some of these points conclude that the social actions of the people of Tinggiran Baru village are based on traditional motives, where the hereditary habits have become common to do. The reasons above also explain why an action is taken without much logical consideration. According to Weber, humans are driven by various interests, material interests, and interests related to a principle or belief. ${ }^{44}$

One of the essential factors that influence people's perceptions and actions is tradition. An activity that is done repeatedly will give birth to a habit, especially if it has been going on from generation to generation; it will gradually become a tradition. This traditional system can form ingrained traits and personalities accompanied by standard rules. It is done repeatedly; a practice usually develops and changes on a specific side; this can occur due to external influences such as religion, technology, and others. ${ }^{45}$

In terms of affective action, the choice to carry out tolak bala of Covid-19 is based on:

1. People anxiety about the potential related to the Covid-19 virus

2. Admiration and love for religious leaders who are said to provide information about repelling Covid-19 reinforcements

3. Hope for a sense of security

${ }^{43}$ I.B Wirawan, Teori-teori Sosial dalam Tiga Paradigma, 101.

${ }^{44}$ I.B Wirawan, Teori-teori Sosial dalam Tiga Paradigma, 69.

${ }^{45}$ Syarifudin, "Tradisi Doa Dana (Tolak Bala) pada Masyarakat Lanta Barat Kecamatan Lambu Kabupaten Bima (Tinjauan Akidah Islam)” Skripsi. Makassar: Ushuluddin Faculty, Philosophy and Politic UIN Alauddin, 2018, 10.

Kodifikasia: Jurnal Penelitian Islam, Volume, 15 No. 2 Tahun 2021 
Let's look at some of these aspects. It is clear that the subjective meaning of individuals shared by the people of Tinggiran Baru's village encourages them to carry out tolak bala as a tradition they believe in, not just loyalty to tradition also as an effort to reduce anxiety and panic.

In social studies, human understanding is different from inanimate objects because human life is full of meaning, ideas, culture, and values. Various aspects inherent in human life as part of society make humans objects and subjects of study so that the psychological dimension greatly determines human relations in society; this is also applied to social actions in the Tinggiran Baru village community where feelings and loyalty to tradition are the dominant motives. ${ }^{46}$

\section{Types of Social Authority and Religious Influence}

If Karl Max views social authority as always determined by economic class in terms of owners of capital, then Weber thinks otherwise. For Weber, the legitimacy of authority in social order can manifest in several types, namely; (1) social-traditional authority, (2) socio-charismatic authority (3) rational socio-legal authority.46

First, in traditional authority, one can gain power because it comes from a descent or family line that traditionally represents the sacredness of specific historical events, so obeying formal authority is considered loyalty to the roots of tradition. If you are in a society that upholds tradition, such authority can influence the masses more strongly than any other authority.

Second, charismatic social authority relates to an assumption that a person has extraordinary advantages that invite admiration and even reverence, usually associated with roles in specific fields, such as community leaders or religious leaders. This type of authority usually carries significant influence as long as the person's charisma does not fade.

Third, rational authority can be interpreted as a form of domination of power that is officially and legally recognized, such as the president, governor, to a smaller level, such as the head of the village. In this type of authority, public compliance is controlled based on laws born from policy forms. ${ }^{47}$

The three types of domination have different levels of influence according to the situation and character of the community itself. However, one person may own the three types of authority; if this happens, then, of course, the resulting dominance will be stronger.

${ }^{46}$ Nurani Soyomukti, Pengantar Sosiologi: Dasar Analisis, Teori 83 Pendekatan menuju Analisis Masalah-masalah Sosial, Perubahan Sosial, Ë Kajian-kajian Strategis, 267.

${ }^{47}$ Pip Jones, Liz Bradbury, and Shaun Le Boutillier, Pengantar Teori-teori Sosial, 120. 
Weber does not deny that a specific "dominating" role is essential in social action. These dominant roles have more power in influencing the activities of the masses, and for some reason, are more obeyed. Referring to the data obtained, compliance with the appeal against the Covid 19 in the village of Tinggiran Baru departs from the immense influence of the charismatic authority, in this case, the late. KH.M. Zaini Bin Abdul Ghani, Sekumpul. The charismatic character of this figure can move the masses, especially to do things that contain Islamic religious narratives, such as rejecting the Covid-19 reinforcements by boiling free-range chicken eggs with a congratulatory prayer.

Regardless of whether this appeal comes from the Guru Sekumpul conveyed through dreams or not, some people with a fast response without feeling the need to clarify obey the information. The charismatic authority related to religious narratives works; the data is swallowed whole because it is on behalf of a highly respected and admired community, even though somebody cannot confirm the arrival of the information from a reliable source.

Weber explicitly discusses the relationship between religious leaders' role and community compliance as a social action closely related to emotional motives such as love, admiration, and hope. If we look closely, the religious narrative in the form of a "safety prayer," which is one part of the procession to prevent the Covid-19 disease, does not have such a significant influence compared to the story about the origin of the information directed at Guru Sekumpul. So, the action is chosen based on "obedience" to specific figures or in the context of preventing the Covid-19 disease in the village of Tinggiran Baru, more directed to "in the name of certain figures."

People believe that tolak bala practice can prevent the spread of Covid-19. Still, some informants admit the information about the tolak bala practice. It does not involve religious figures that they glorify, so they will undoubtedly hesitate to carry out the appeal even though there is a congratulatory prayer in the process itself.

\section{CONCLUSION}

The community in Tinggiran Baru Village responded to the spread of Covid-19 by tolak bala. The suggestion allegedly came from the information that $\mathrm{KH}$. Zaini bin Abdul Ghani was conveyed to one of his children through a dream; the data was then obtained by someone who claimed to live in Martapura, close to the residence of the Guru Sekumpul. However, the accuracy of this information cannot be guaranteed because there are various other versions of recommendations to practice tolak bala. 
There are several conclusions regarding the motives for the obedience of the people of Tinggiran Baru Village to carry out the tolak bala amidst the uncertainty of the source. First, the reason for traditional actions which involve people's habits for generations to carry out certain rituals of tolak bala when faced with situations that are considered dangerous. Second, the motive for affective action as an action based on emotional factors and the dominance of the feelings of the people in Tinggiran Baru Village facing the Covid-19 Pandemic, such as feelings of fear, anxiety, expecting selfsecurity, as well as admiration and love for religious leaders that trigger obedience. Third, the charismatic factor of religious figures as the source of the recommendation of tolak bala practice is the most influential on the community, thus creating social compliance only in the name of this charismatic figure.

Some views on the type of social action that became the motive for the Covid-19 tolak bala activity in the Tinggiran Baru Village: are traditional and affection; it can be seen that critical culture has not dominated the social efforts of the local community. The crucial culture in question is logical consideration when determining an effort, clarifying unclear information, and more importantly, not being too easy to believe in a recommendation, especially those with a strong basis. Reasonable standards in community social action are essential, especially when facing a health emergency today; it allows the public not to be easily swayed by hoaxes, unfounded information, and even more so containing certain religious narratives.

Information and recommendations that have a clear basis and source, such as government recommendations and policies, health protocols, and MUI fatwas, should be more socialized to the public so that the actions chosen are also appropriate. The socialization should also involve community leaders or religious leaders who are charismatic in the community's eyes so that the potential for compliance with these recommendations is tremendous. 


\section{REFERENCES}

Abidah, Azmil, Hasan Nuurul Hidaayatullaah, Roy Martin Simamora, Daliana Fehabutar, and Lely Mutakinati. "The Impact of Covid-19 to Indonesian Education and Its Relation to the Philosophy of "Merdeka Belajar." Studies in Philosophy of Science and Education 1, no. 1 (April 1, 2020): 38-49. https://doi.org/10.46627/sipose.v1i1.9.

Alkaf, M. "Agama, Sains, Dan Covid-19: Perspektif Sosial-Agama." MAARIF 15, no. 1 (June 30, 2020): 93-108. https://doi.org/10.47651/ mrf.v15i1.79.

Aquarini, Aquarini. "Pengaruh Kebijakan Politik Terhadap Kepatuhan Physical Distancing Mencegah Penyebaran Covid-19.” Anterior Jurnal 19, no. 2 (June 30, 2020): 66-73. https://doi.org/10.33084/anterior. v19i2.1498.

Arrobi, Mohammad Zaki, and Amsa Nadzifah. "Otoritas Agama di Era Korona: Dari Fragmentasi Ke Konvergensi?" MAARIF 15, no. 1 (June 30, 2020): 197-215. https://doi.org/10.47651/mrf.v15i1.85.

Aula, Siti Khodijah Nurul. "Peran Tokoh Agama Dalam Memutus Rantai Pandemi Covid-19 Di Media Online Indonesia." Living Islam: Journal of Islamic Discourses 3, no. 1 (June 28, 2020): 125-48. https://doi. org/10.14421/lijid.v3i1.2224.

Blbas, Hazhar Talaat Abubaer, Kareem F. Aziz, Sahar H. Nejad, and Azeez A. Barzinjy. "Phenomenon of Depression and Anxiety Related to Precautions for Prevention among Population during the Outbreak of COVID-19 in Kurdistan Region of Iraq: Based on Questionnaire Survey." Zeitschrift Fur Gesundheitswissenschaften = Journal of Public Health, June 10, 2020, 1-5. https://doi.org/10.1007/s10389-020-013259.

Buana, Dana Riksa. "Analisis Perilaku Masyarakat Indonesia dalam Menghadapi Pandemi Virtus Corona (Covid-19) dan Kiat Menjaga Kesehatan Jiwa" Laporan Penelitian. Jakarta: Fakultas Psikologi Nasional Research Tomsk State, 2020.Jones, Pip, Liz Bradbury, dan Shaun Le Boutillier. Pengantar Teori-teori Sosial, terj. Achmad Fedyani Saifuddin. Jakarta: Yayasan Pustaka Obor Indonesia, 2016. 
Cao, Wenjun, Ziwei Fang, Guoqiang Hou, Mei Han, Xinrong Xu, Jiaxin Dong, and Jianzhong Zheng. "The Psychological Impact of the COVID-19 Epidemic on College Students in China." Psychiatry Research 287 (May 2020): 112934. https://doi.org/10.1016/j.psychres.2020.112934.

Hart, Curtis W., and Harold G. Koenig. "Religion and Health During the COVID-19 Pandemic." Journal of Religion and Health 59, no. 3 (June 2020): 1141-43. https://doi.org/10.1007/s10943-020-01042-3.

Haryanto, Sindung. Spektrum Teori Sosial : Dari Klasik Hingga Kontemporer. Yogyakarta: Ar-Ruzz Media, 2012.

Hasbullah, Toyo and Awang Azman Awang Pawi. "Ritual Tolak Bala pada Masyarakat Melayu (Kajian pada Masyarakat Petalangan Kecamatan Pangkalan Kuras Kabupaten Pelalawan)". Jurnal Ushuluddin, Vol. 25, No. 1, January 2017.

Hidayah, Nur. "Dari Jabariyah, Ke Qadariyah, Hingga Islam Progresif: Respons Muslim Atas Wabah Corona Di Indonesia." SALAM: Jurnal Sosial Dan Budaya Syar-i 7, no. 5 (April 17, 2020): 423-38. https://doi. org/10.15408/sjsbs.v7i6.15365.

Isbaniah, Fathiyah et.al. Pedoman Kesiap-siagaan Mengahadapi Coronavirus Disease (Covid-19). Jakarta: Kementerian Kesehatan RI, Direktorat Jenderal Pncegahan dan Pengendalian Penyakit (P2P), 2020.

Kahmad, Dadang, Wawan Hernawan, Tatang Zakaria, and Tias Febtiana Sari. "Ritual Azan Pitu sebagai upaya mencegah penyebaran wabah Covid-19 di Cirebon." Monograph. Karya Tulis Ilmiah Dosen UIN Sunan Gunung Djati Bandung. UIN Sunan Gunung Djati Bandung: Fakultas Ushuluddin, May 2, 2020. http:/digilib.uinsgd.ac.id/30628/.

Kuswana, Dadang, Bambang Qomaruzzaman, and Masmuni Mahatma. "Agama Dan Wabah : Tanggapan Ulama Jawa Barat Atas Covid-19 Tahun 2020.” UIN Sunan Gunung Djati Bandung, 2020. http://digilib. uinsgd.ac.id/30780/.

Majelis Ulama Indonesia. "Fatwa Majelis Ulama Indoesia Nomor 14 Tahun 2020 tentang Penyelenggaraan Ibadah dalam Situasi Terjadi Wabah Covid-19”. Jakarta: Komisi Fatwa MUI, 2020.

Majelis Ulama Indonesia. "Fatwa Majelis Ulama Indoesia Nomor 17 Tahun 2020 tentang Pedoman Kaifiat Shalat Bagi Tenaga Kesehatan yang Memakai Alat Pelindungan Diri (APD) Saat Merawat dan Menangani Pasien Covid-19”. Jakarta: Komisi Fatwa MUI, 2020. 
Majelis Ulama Indonesia. "Fatwa Majelis Ulama Indoesia Nomor 18 Tahun 2020 tentang Pedoman Pengurusan Jenazah (Tajhiz Al-Jana’iz) Muslim yang Terenfeksi Covid-19”. Jakarta: Komisi Fatwa MUI, 2020.

Majelis Ulama Indonesia. "Fatwa Majelis Ulama Indoesia Nomor 28 Tahun 2020 tentang Panduan Kaifiat Takbir dan Shalat Idul Fitri Saat Pandemi Covid-19”. Jakarta: Komisi Fatwa MUI, 2020.

Modell, Stephen M., and Sharon L. R. Kardia. "Religion as a Health Promoter During the 2019/2020 COVID Outbreak: View from Detroit." Journal of Religion and Health 59, no. 5 (October 1, 2020): 2243-55. https://doi. org/10.1007/s10943-020-01052-1.

M. Idhom Adidi, "Update Corona 15 Mei 2020 di Indonesia dan Dunia: Data kasus Terkini" dalam https://amp.tirto.id/update-corona-15-Mei2020-di-indonesia-dunia-data-kasus-terkini-fumo. accessed on 15 May 2020.

Purtamasari, Deti Mega. "Kebijakan Presiden Terkait Penanganan Covid-19 disebut Bisa Berubah" dalam https://amp.kompas.com. accessed on 15th May 2020.

Sampurno, Muchammad Bayu Tejo, Tri Cahyo Kusumandyoko, and Muh Ariffudin Islam. "Budaya Media Sosial, Edukasi Masyarakat, dan Pandemi COVID-19." SALAM: Jurnal Sosial dan Budaya Syar-i 7, no. 6 (April 14, 2020): 529-42. https://doi.org/10.15408/sjsbs.v7i5.15210.

Setyadi, Yusuf. "Social And Security Impact Of Covid-19 Outbreak In West Kalimantan Based On The Police Law Perspective." Syariah: Jurnal Hukum Dan Pemikiran 20, no. 1 (July 2, 2020): 13-26. https:// doi.org/10.18592/sjhp.v20i1.3771.

Shihab, M. Quraish. Corona Ujian Tuhan: Sikap Muslim Menghadapinya. Tangerang: Lentera Hati, 2020.

Sihaloho, Estro Dariatno. "Dampak Covid-19 Terhadap Perekonomian Indonesia". Bandung: Departemen Ilmu Ekonomi Universitas Padjadjaran, 2020.

Soyomukti, Nurani. Pengantar Sosiologi: Dasar Analisis, Teori $\mathcal{E}$ Pendekatan menuju Analisis Masalah-masalah Sosial, Perubahan Sosial, 83 Kajiankajian Strategis. Cet II, Yogyakarta: Ar-Ruzz Media, 2014.

Sugiyono. Metode Penelitian Kualitatif. Bandung: Alvabeta, 2018.

Syarifudin, "Tradisi Doa Dana (Tolak Bala) pada Masyarakat Lanta Barat Kecamatan Lambu Kabupaten Bima (Tinjauan Akidah Islam)" Skripsi, 
Makassar: Fakultas Ushuluddin, Filsafat dan Politik UIN Alauddin, 2018.

Wirawan, I.B. Teori-teori Sosial dalam Tiga Paradigma. Cet IV, Jakarta: Kencana, 2015.

Yanti, Budi, Eko Mulyadi, Wahiduddin Wahiduddin, Revi Gama Hatta Novika, Yuliana Mahdiyah Da'at Arina, Natalia Sri Martani, and Nawan Nawan. "Community Knowledge, Attitudes, And Behavior Towards Social Distancing Policy As Prevention Transmission of Covid-19 In Indonesia." Jurnal Administrasi Kesehatan Indonesia 8, no. O (June 17, 2020): 4-14. https://doi.org/10.20473/jaki.v8i0.2020.4-14.

ZA, Safrizal et.al, Pedoman Umum Menghadapi Pandemi Covid-19. Jakarta: Tim Kerja Kementerian dalam Negeri untuk Dukungan Gugus Tugas Covid-19, 2020. 